\title{
THE ANALYSIS OF THE STATE SPACE OF MANAGEMENT PROCESS IN THE INDUSTRY APPLYING EXPERT SYSTEMS
}

\author{
Irina Dmitrevna Ivanova ${ }^{\mathrm{a}}$, Andreev Viktorovich Sergutenko ${ }^{\mathrm{a}}$, Jan Radosław Kamiński ${ }^{\mathrm{b} *}$, \\ Maciej Kubońc \\ ${ }^{\text {a }}$ Department of Automation of Technological Process and Production, \\ Mogilev State University of Food Stuffs, Belarus \\ b Department of Agricultural and Forest Machinery, Warsaw University of Life Sciences - SGGW \\ c Institute of Agricultural Engineering and Informatics, University of Agriculture in Krakow \\ "Corresponding author: e-mail: jan_kaminski@sggw.pl
}

\begin{tabular}{|c|c|}
\hline ARTICLE INFO & ABSTRACT \\
\hline $\begin{array}{l}\text { Article history: } \\
\text { Received: September } 2016 \\
\text { Received in the revised form: } \\
\text { December } 2016 \\
\text { Accepted: January } 2017 \\
\end{array}$ & $\begin{array}{l}\text { The article includes analysis of expert system application possibilities } \\
\text { in the environment of production processes control. Such concepts as } \\
\text { artificial intelligence, expert system, intellectual factor, state space } \\
\text { were used. The object of the research consisted of the mechanism of } \\
\text { controlling an enterprise (manager). These mechanisms were analysed }\end{array}$ \\
\hline $\begin{array}{l}\text { Key words: } \\
\text { expert system, } \\
\text { analysis, } \\
\text { process, } \\
\text { production, } \\
\text { stability }\end{array}$ & $\begin{array}{l}\text { from the point of view of state space. The graph method was used to } \\
\text { visualize information presentation. Analysis of control processes of an } \\
\text { enterprise was carried out by determination of their state space. The } \\
\text { concept of state space itself is completed with numerous measurement } \\
\text { values (parameters) under influence of which the process of task } \\
\text { solution takes place. Moreover, the concept of static and dynamic } \\
\text { elements of state space of the control system is applied. It was shown } \\
\text { that dynamic elements enable the quality presentation of space, which } \\
\text { without including other restrictions leads to extension of its impact, } \\
\text { which confirms that a given system has an intelligent factor. }\end{array}$ \\
\hline
\end{tabular}

\section{Introduction}

Nowadays enterprises and industries are well equipped with automation facilities due to modern development of science. Through the introduction of new technologies, companies are able to re-equip their production capacity with modern lines, which means producing competitive products, reducing costs and having a high-tech production in general.

Recent development of information technology allows introduction of the results of artificial intelligence research into the area of economics. Herbert Simon (1916-2001) was one of its first researchers to receive the Nobel Prize in economics. It happened in 1976 (Абрамов, 1998; Луценко and Лойко, 2005; Рассел and Норвиг, 2006). Applying artificial intelligence to economic and management processes has been of great interest to the international community since the 90s of the last century up to the present (Велман, 1995). Producers of worldwide brands are paying great attention to the introduction of such technologies into business processes. 
One way of the applying intelligent agents (Велман, 1995; Сагальников, 2008; Ковалев and Волкова, 2000; Нестеров and Нестеров, 2016) is automation of enterprise management.

First of all, its optimization of managerial decisions in accordance with realization of an enterprise business strategy and its economic opportunities should be carried out. Secondly, drawing up a plan of accomplishing the task, and finally, control of the proper execution of each item of the plan should be ensured.

Foreign companies widely use expert systems in these developments. For example, American Express uses the expert system to determine whether it is expedient to give a loan to a company. Japanese Sanwa Bank, one of the world's largest banks, applies the expert system Best Mix to improve the quality of their information on investments (Андрейчиков and Андрейчикова, 2004; Литвик 2004; Тельнов, 1999).

The expert system is a computer program that operates with knowledge in a particular branch to provide advice or solutions to problems. (Рассел and Норвиг, 2006; Телков, 2007).

The most important feature of these expert systems is the possibility of making decisions in unique situations, for which an algorithm is not known in advance and is formed from the initial data in the form of a line of reasoning (decision rules) from the knowledge base. The tasks are expected to be carried out in conditions of incomplete, unreliable, multiple initial data and qualitative assessments of the processes (Телков, 2007; Литвак, 2004). It becomes possible due to the adaptive properties of the expert system. It means that the behavior of the program implementing this system is changing (for the better) during a certain period of time (Алфеева, 2006; Нейлор, 1991; Романов and Одинцов, 2000; Романов, 2003).

Management automation is impossible without an analysis of existing management mechanisms, including both economic and psychological factors.

This article analyses availability of certain algorithmic dependencies of existing structural elements of an enterprise. It defines static and dynamic characteristics. The mechanism of their transformation, linkages between them and their interference are shown in the context of this term.

\section{Dynamic and static state spaces}

In modern conditions, effective management represents a valuable resource of the organization, along with financial, material, human and other resources. Consequently, improving efficiency of management becomes one of the directions to improving enterprise activity as a whole. The most obvious way to perfect the efficiency of working process is its automation. But the way, that is effective for strictly formalized production process, isn't obvious for such a delicate sphere as management (Дидук and Прад, 1986; Нестеров and Нестеров, 2016).

Management solution is a complex of social, economic and psychological events aligned in a certain sequence. Changing this sequence both in its horizontal structure and in its depth (qualitative performance) can influence the outcome of the entire complex.

This particular sequence can be characterized by a number of state spaces.

The term state space is widely used in a similar kind of literature and is regarded as a set of all states achievable from the initial state (Нестеров and Нестеров, 2016), which charac- 
The analysis of the state...

terizes the search for a solution of the problem as a process of finding solutions (chains leading to a solution of the problem) from the initial state to the target one (Michalski and Chilausky, 1980; Нейлор, 1991).

However, I would not use this terminology for description of a uniform physical environment, like a plane, and would associate it with the elements absolutely incompatible from the existing point of view, for example, a plane, prime cost, the number of working days a year and the number of products.

The approach to solving problems using state spaces got its name by analogy with the situation in the theory of management, in which state spaces are also used for similar purposes (Джарратано and Райли, 2006; Нильсон, 1973).

The state space (D) can be defined not only as a set of states achievable from the initial state, but also as a set of measured values (parameters) that lead to carrying out problemsolving process from the initial state to a whole.

For example, the quantity (Q) is an element of the state space in our case as well, because it can be measured; location of an object in the universe can be described using the system of coordinates $\mathrm{x}, \mathrm{y}, \mathrm{z}$; various locations of the object can also be viewed as completely different.

where:

$$
\mathrm{D}=(\mathrm{Q}, \mathrm{S}, \ldots, \mathrm{N})
$$

$\mathrm{S}=\{\mathrm{Si}\}, \mathrm{i}=1,2,3, \ldots, \mathrm{n} . \mathrm{S}-\mathrm{a}$ set of locations of the object in the analyzed space

$\mathrm{Q}=\{\mathrm{Qi}\}, \mathrm{i}=1,2,3, . ., \mathrm{n}, \mathrm{Q}-$ quantitative characteristic of the object

$\mathrm{N}=\{\mathrm{Ni}\}, \mathrm{i}=1,2,3, . ., \mathrm{n}, \mathrm{N}$ - other parameters of the object, for example, speed, mass, desity, and so on (Even price or its prime cost can be measured values in our space.)

I propose to consider this kind of a space as a set of static and (or) dynamic elements.

A distinctive feature of dynamic elements is the ability to change their own values.

$\mathrm{D}(\mathrm{x})=\mathrm{f}(\mathrm{Q}, \mathrm{S}, \ldots, \mathrm{N})$

Any dynamic element consists of a certain number of spatial states. This number can be changed under the influence of other dynamic elements. The main core of a dynamic element is a static space that can be described by the number of states. The number can be neither decreased nor increased, because changes within it will lead to the destruction or to the reshaping of this space.

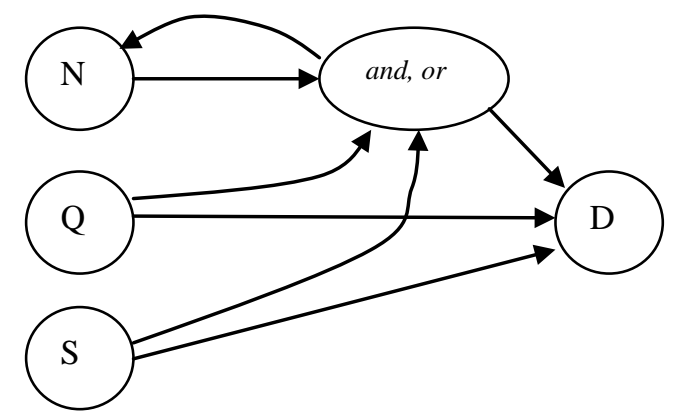

Figure 1. Example of state space 
In this figure 1 the states $\mathrm{S}$ and $\mathrm{Q}$ are static space. $\mathrm{N}$ is changeable special states. The set of $\mathrm{N}, \mathrm{Q}, \mathrm{S}$ forms a dynamic element.

A numerically programmed machine can be demonstrated as an example of a static state space which can be called the world of a numerically programmed machine. This machine is an agent in this world. The world is possible for the agent if it doesn't contradict anything the agent knows (Рассел and Норвиг, 2006).

To make a complete presentation of our problem in the state space it's enough to specify the following points:

1. The form of state description and, in particular, the description of the initial state;

2. Operators and their impact on the state description (Нильсон, 1973).

In this case, the concept of world can be interpreted as a set of boundaries of the trajectories of physical motions of the controlled mechanism of a numerically programmed machine in the space, and can perform a way of state description. The state space of the machine is physical positions specified by a program to produce a component. It's logical to assume, that the initial state is position 1 . If the algorithm for the production of the component requires making 4 steps, it means that the static space of the machine has 4 positions. The number of spatial positions can be neither increased nor decreased, as it would change the boundaries of its world and reshape its static space.

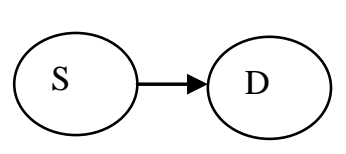

where $\mathrm{S}=$

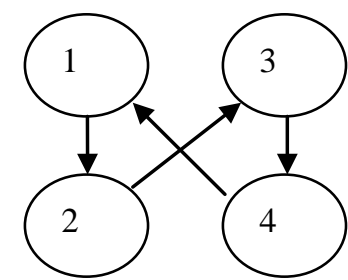

Figure 2. State space consisting of 4 positions of numerically programmed machine

The figure 2 shows the state space consisted of 4 positions of numerically programmed machine.

$$
\mathrm{D}(\mathrm{x})=\mathrm{f}(\mathrm{S}) \text {, where } \mathrm{S}=\{\mathrm{Si}\}, \mathrm{i}=1 . .4 \text {. }
$$

Changing the machine's operations from one position to another is carried out under the influence of a certain effect on its condition. In other words, the static space consisted of 4 spatial states in our example was imposed on the numerically programmed machine by a program or an algorithm. P is a dynamic element in the algorithm. It's logical to assume, that this algorithm can impose both 8 spatial states and 2 spatial states on the machine (Fig. 3). 
The analysis of the state...

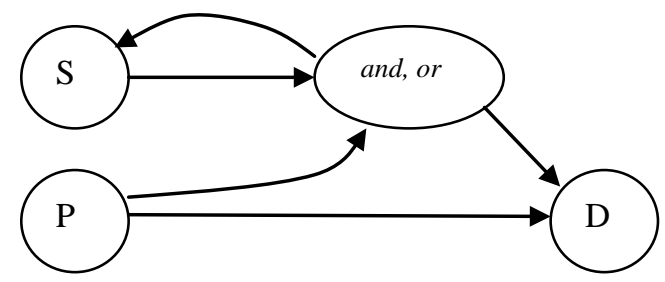

Figure 3. The state space of numerically programmed machine

where:

$$
\mathrm{D}=(\mathrm{P}, \mathrm{S})
$$

$\mathrm{S}=\{\mathrm{Si}\} \mathrm{i}=1,2,3, \ldots, \mathrm{n}$

$\mathrm{S}-\mathrm{a}$ set of spatial states of a numerically programmed machine

$\mathrm{P}=\{\mathrm{Pi}\}, \mathrm{i}=1,2,3, . ., \mathrm{n}, \mathrm{P}-\mathrm{a}$ dynamic component of the space, the algorithm of the machine

$$
\mathrm{S}(\mathrm{x})=\mathrm{f}(\mathrm{P})
$$

In any case, the spatial state can also be described as a matrix (Table 1).

Table 1.

Matrix of the spatial state

\begin{tabular}{lllcc}
\hline & $\mathrm{S}$ & $\mathrm{P}$ & Logic & $\mathrm{D}$ \\
\hline $\mathrm{S}$ & 0 & 0 & 1 & 0 \\
$\mathrm{P}$ & 0 & 0 & 1 & 1 \\
$\mathrm{~L}$ & 1 & -1 & 0 & 1 \\
$\mathrm{D}$ & 0 & -1 & -1 & 0 \\
\hline
\end{tabular}

It is logical to assume, that the state space of a numerically programmed machine is a closed static system, provided, that the machine only has static elements. On the other hand, the static system of a numerically programmed machine is the core of the dynamic system of the workshop where the machine operates. The dynamic system may have additional spatial states, like the number of components (NQ), the number of working day hours (NT), etc. (Fig. 4).

$$
\mathrm{D}=(\mathrm{P}, \mathrm{S}, \mathrm{NT}, \mathrm{NQ})
$$

It becomes clear that additional spatial states can fall under influence and be updated by neighboring dynamic spaces. For example, the dynamic space of the supply department at an enterprise, where the numerically programmed machine operates, can update the number of dynamic state spaces of the workshop. 


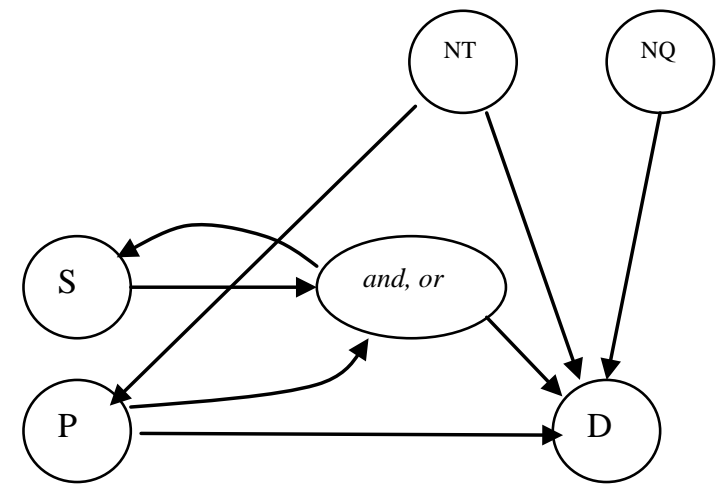

Figure 4. The state space of machine with additional spatial states

\section{Intelligent agents of dynamic spaces and their interference}

Dynamic space must be able to respond to the influence of surrounding dynamic spaces by increasing or decreasing the number of their own states. Dynamic space unlimited by the influence of neighboring dynamic spaces tends to increase the number of its dynamic states and the quality of their presentation.

By the example of a workshop, where a numerically programmed machine operates, it will look as follows. We must define the state spaces of the following elements:

NS - supply department;

NK - personnel department;

$\mathrm{NF}$ - finance department;

NT - the workshop where the numerically programmed machine operates;

$\mathrm{NC}$ - sales department.

Let us assume that NS, NK, NF, NC, NT have dynamic elements, i.e. the abovementioned spaces are dynamic.

The dynamic space of the supply department (NS) limits the dynamic space of the workshop (NT) by controlling the number of components (NQ) to be produced by our machine. The dynamic space of the personnel department (NK) limits working time of the machine up to one shift. We should remove these limits. The numerically programmed machine works in its world consisting of 4 states. However, the number of components (NQ) produced by the machine has increased. The dynamic space of the workshop (NT) has changed the number of produced components (NQ) by itself, and thus significantly influenced the dynamic space of the sales department (NC) and the finance department (NF). 
The analysis of the state...

$$
\begin{gathered}
\mathrm{P}=\text { const; } \mathrm{S}=\text { const } \\
\mathrm{NT} \rightarrow \max ; \mathrm{NQ} \\
\text { Since } \mathrm{D}(\mathrm{x})=\mathrm{f}(\mathrm{P}, \mathrm{S}, \mathrm{NT}, \mathrm{NQ}, \mathrm{NS}, \mathrm{NK}, \mathrm{NF}, \mathrm{NC})
\end{gathered}
$$

where:

$\mathrm{NS}=\mathrm{NK}=0$, then $\mathrm{D}(\mathrm{x}) \rightarrow \max$;

Each spatial element in the world around us has either dynamic or static state space. In other words, the dynamic space must possess intelligence, i.e. contain at least one intelligent agent. Each intelligent agent has a certain number of spatial states and at the same time tends to increase this number. The measurement of the space of each intelligent agent is defined by the measurements of the spaces of neighboring intelligent agents. That is, each intelligent agent may influence the state space of its neighbor.

Agents are autonomous, i.e. they must operate without direct interference of the general controlling process. Thus, they control their own actions and internal state. Besides, the agent must sense the condition of the local environment, as well as be able to foresee situations (Люгер, 2003; Винаров, 2006).

There is also a hierarchy of intelligent agent classes in a dynamic structure, the so-called subordination structure. This structure allows exerting influence on junior neighboring dynamic spaces and adjusting the influence of neighbors on the side.

$$
\mathrm{f}(\mathrm{p})+\mathrm{f}(\mathrm{s})+\ldots .+\mathrm{f}(\mathrm{n})+\mathrm{f}(\mathrm{i}) \rightarrow 0
$$

where:

$\mathrm{f}(.$.$) - the result of the influence of a static or a dynamic component.$

As we can see from this formula, the total result of influences in the equilibrium dynamic system must tend to " 0 ". Consequently, an intelligent agent must remain responsive to other agents when discussing tasks, goals and corresponding processes (Люгер, 2003)

Therefore, a set of dynamic and static systems in the economic model can represent both dynamic and static systems, depending on the state space allotted by a senior dynamic system.

Let us demonstrate it with an example of our numerically programmed machine. Let us suppose that the machine itself is a static element as mentioned above. The workshop where the machine operates is a dynamic element. The plant where the workshop is situated is also a dynamic element. All the mentioned above is discussed in terms of the numerically programmed machine.

If $\mathrm{P}=$ min // implying that $\mathrm{P}$ is the total result of influences, i.e. the system is equilibrium

Then D:=static // The space is considered as a static one in terms of the senior system.

Else D:=dynamic; // The space is considered as a dynamic one in terms of the system itself.

Thus, we can draw a conclusion, that everything, that is located outside our static system and belongs to a senior dynamic system, is considered as a dynamic system in terms of 
our static system. And similarly, vice versa, everything that belongs to a class lower than ours is considered as a static system, and we are a dynamic system for them and can provide a junior class with dynamic spaces or deny them this right. It is logical to assume, that the dynamic space devoid of dynamic spatial states becomes static and the static space can become dynamic being provided with at least one dynamic state.

It is also worth mentioning that the plant in our example can be considered as a static element with a rather limited number of spatial states in terms of the nation's economics. The decrease of this number will lead to the destruction of its static system that is highly dynamic in terms of static elements within the plant.

The sequence of intelligent agent transitions from one spatial state to another is determined by a dynamic algorithm based on a mathematical model. This model allows searching for optimal solutions, determining their costs by the method of goals dissection and followers selection. This method of spatial state analysis is the basis of the mathematical model.

Applying the works on artificial intelligence in economics will provide reliable decision-making in an atmosphere of uncertainty. In other words, in cases when the analyzed sphere cannot be determined with set boundaries or defined by precise formulas because of presence of other objects that can influence the outcome of the whole system and their neighbors' activity in the environment (Нестеров and Нестеров, 2016).

\section{Conclusions}

Artificial Intelligence, as an area of academic knowledge, originally had a rather narrow range of traditional problems. The list of these problems and their formulations became narrower with the development of that science. Finally, the area of study was divided into a number of particular problems. Some of them can be solved; others have no solutions as they cannot be solved with modern methods, because there is no proof of impossibility to solve them (Смолин et al., 2004).

The methods of artificial intelligence became widely known in practice due to the creation of a special class of programs called expert systems.

In fact, applied intelligent systems are used in tens of thousands of applications nowadays. And the annual income from selling software and hardware of artificial intelligence in the USA amounted to 870 million dollars as early as in 1989, and 1.1 billion dollars in 1990 (Попов et al., 1996). Later on, nearly thirty percent of income growth gave way to a gradual rate of growth (from the works of (Choroszewski, 2016; Частников et al., 2003; Kata, 2010; Miller, 1987; Ziemba and Obłąk, 2012).

Nowadays expert systems, being highly tailored software systems, are widely used by enterprises for making decisions not only in the sphere of technical process control, but also for making ruling decisions in enterprise management (Рассен and Норвиг, 2006).

The article describes the analysis of management processes at an enterprise by means of determining their state spaces. The term state space is complemented with a number of measurable values (parameters) that accomplish problem-solving process from the initial state to the whole.

The example of a numerically programmed machine shows that the state space of any system includes a static and (or) a dynamic component. Dynamic components organize 
The analysis of the state...

a qualitative presentation of space that tends to extend its influence in the absence of outside limiters, which allows asserting that this system has an intelligent agent.

The influence of intelligent agents gets mutually balanced in the equilibrium system, thus the result of spatial influence tends to zero in the equilibrium system. It can be explained by the fact that agents are autonomous (Лютер, 2003).

On the grounds of the conclusions from the article, it is supposed to work out an algorithm of searching and coming to decisions, which can be applied in expert systems of enterprise management.

\section{References}

Абрамов, А.А. (1998). Моделирование информачионных процессов в системе управления промышленного предприятия. Москва. Наука, 103.

Алфеева, Е.Л. (2006). Модель информационной среды профессиональной деятельности в образовании. Информационные технологии. № 10, 65-71.

Андрейчиков, А.В., Андрейчикова, О.Н. (2004). Интеллектуальные информационные системы. Издательство Наука, Финансы и статистика, Москва, 464.

Велман, Н.П. (1995). Экономический подход к искусственному интеллекту. АСМ Computing Surveys, 154.

Винаров, А.Ю. (2006). Биодобавки для роста растений и рекультивации почв: Экспертныйподход к выбору и применению. Москва: ДеЛи принт, 152.

Сагальников, С.Г. (2008). Теоретические и прикладные проблемы аграрной информатики. ВИАПИ. Москва. 263.

Choroszewski, T. (2016). Lokalny program rozwoju przedsiębiorczości dla miasta Ostrołęki na lata 2006-2010 (online). Obtained from: http://www.ostroleka.pl/doc/Przydatne_dokumenty /2006.09.11_LPP.pdf.

Смолин, В.Д. (2004). Введение в искусственный интеллект. Издательство Физмалит. Москва, 208.

Частиков, А.П., Гаврилова, Т.А., Белов, Д.Л. (2003). Разработка экспертных систем, среда CLIPS. БХВ-Петербург, 608.

Джарратано, Д., Райлин, Г. (2006). Экспертные системы: Принципь разработки и программирование. Издательство Вильямс, Москва, 1152.

Дидук, Д., Прад, А. (1986). К анализу и синтезу нечетких отображений. Нечеткие множества и теория возможностей. (Под ред. Ягера Р.Р.), перевод с английского. Москва. Радио и Связь, 229-240.

Kata, R. (2010). Znaczenie banków lokalnych w dostępie rolników do kredytów bankowych. (The Importance of Local Banks to Accessing of Farmers to Bank Credit). Roczniki Nauk Rolniczych. Seria G. Ekonomika Rolnictwa, z. 4, 95-104.

Ковалев, В.В., Волкова, О.Н. (2000). Анализ хозяйственной деятельности предприятия. Москва. ПБОЮЛ Гриженко Е.М., 424.

Литвак, Б.Г. (2004). Экспертные технологии в управлении. Издательство Дело. Москва, 68.

Люгер, Дж. (2003). Стратегии и методы решения сложных проблем. Издательство Вильямс, Москва, 864.

Луценко, Е.В. Лойко, В.И. (2005). Семантические информачионные модели управления агропромышленным комплексом. Краснодар. КубанГАУ, 480.

Michalski, R.S., Chilausky, R. L. (1980). Knowledge acquisition by encoding expert rules versus computer induction from examples a case study involving soybean pathology. International Journal of Man-Machine Studies. Vol. 12, 63-87. 
Miller, D. (1987). The Structural and Environment Correlates of Business Strategy, Strategic Management Journal, No 8, 26-34.

Нейлор, К. (1991). Как построить свою экспертную систему. Энергоатомиздат, Москва, 283.

Нестеров, В.П., Нестеров, И.Б. (2016). Автоматизащия деятельности организации (online). Obtained from: http://bvp.h1.ru/docum/avtomat/avtomat.html.

Нильсон, Н. (1973). Искусственный интеллект. Методы поиска решений. Мир, Москва, 273.

Попов, Э.Ф., Фоминых, И.Б., Кисель, Е.Б., Шапот, М.Д. (1996). Статические и динамические экспертные системы: Учебное пособие для спеиялистов. Прикладная математика. Автоматизированные системы обработки и управления. Москва. Финансы и статистика, 319.

Рассел, С., Норвиг, П. (2006). Искусственный интеллект. Современный подход, 2-е издание издательство Вильямс, Москва, 1407.

Романов, А.Н., Одинцов, Б.Е. (2000). Советующие информационные системы в экономике: Учебное пособие для вузов. Москва. ЮНИТИ-ДАНА, 487.

Романов, В.П. (2003). Интеллектуальные информачионные системы в экономике (Под ред. Н. П. Тихомирова). Москва. Издательство Экзамен, 496.

Телков, А.Ю. (2007). Экспертные системы. Учебное пособие для вузов. Воронеж, 82.

Тельнов, Ю.Ф. (1999). Интеллектуальные информационные системы в экономике. Учебное пособие для студентов вузов. Издательство Синтег. Москва, 214.

Ziemba, E., Obłąk, I. (2012). Systemy informatyczne w organizacjach zorientowanych procesowo. Wydział Zarządzania UW. Problemy Zarzadzania, Vol. 10, 3(38), 8-21.

\section{ANALIZA ZASTOSOWANIA SYSTEMU EKSPERCKIEGO W STEROWANIU PROCESAMI PRODUKCYJNYMI}

Streszczenie. W artykule przeprowadzono analizę możliwości zastosowania systemów eksperckich, w takim środowisku, jak sterowanie procesami produkcyjnymi. Wykorzystano terminy: sztuczna inteligencja, system ekspercki, czynnik intelektualny, przestrzeń stabilności. Obiektem badań były mechanizmy sterowania przedsiębiorstwem (menażerstwa). Mechanizmy te analizowano z punktu widzenia stabilności przestrzennej. W artykule wykorzystano metode grafów w celu wizualnego przedstawienia informacji. Przeprowadzono analizę procesów sterujących przedsiębiorstwem drogą wyznaczenia ich przestrzeni stabilności. Sam termin przestrzeń stabilności uzupełniany jest licznymi wielkościami pomiarowymi (parametrami), pod wpływem których zachodzi proces rozwiązania zadania. Także stosowane jest pojęcie statycznych i dynamicznych składowych przestrzeni stabilności systemu sterowania. Pokazano, że składowe dynamiczne umożliwiają jakościowe przedstawienie przestrzeni, które przy nie uwzględnianiu innych ograniczeń prowadzi do rozszerzenia swego oddziaływania, co utwierdza o posiadaniu przez dany system inteligentnego czynnika.

Słowa kluczowe: system ekspercki, analiza, proces, produkcja, stabilność 